\title{
Pet or pest? Stable isotope methods for determining the provenance of an invasive alien species
}

\author{
Katherine G. W. Hill', Kristine E. Nielson², Jonathan J. Tyler², \\ Francesca A. McInerney ${ }^{2}$, Zoe A. Doubleday ${ }^{3}$, Greta J. Frankham ${ }^{4}$, \\ Rebecca N. Johnson ${ }^{4,5}$, Bronwyn M. Gillanders', Steven Delean', Phillip Cassey' \\ I School of Biological Sciences and the Environment Institute, The University of Adelaide, Adelaide, South \\ Australia, Australia 2 Department of Earth Sciences and Sprigg Geobiology Centre, University of Adelaide, \\ Adelaide, South Australia 3 Future Industries Institute, University of South Australia, Adelaide, South Austra- \\ lia, Australia 4 Australian Centre for Wildlife Genomics, Australian Museum Research Institute, Sydney, New \\ South Wales, Australia 5 Smithsonian National Museum of Natural History, Washington, D.C., USA \\ Corresponding author: Katherine Hill (katherine.hill@adelaide.edu.au)
}

Academic editor: E. García-Berthou | Received 27 April 2020 | Accepted 29 May 2020 | Published 28 July 2020

Citation: Hill KGW, Nielson KE, Tyler JJ, McInerney FA, Doubleday ZA, Frankham GJ, Johnson RN, Gillanders BM, Delean S, Cassey P (2020) Pet or pest? Stable isotope methods for determining the provenance of an invasive alien species. NeoBiota 59: 21-37. https://doi.org/10.3897/neobiota.59.53671

\begin{abstract}
The illegal pet trade facilitates the global dispersal of invasive alien species (IAS), providing opportunities for new pests to establish in novel recipient environments. Despite the increasing threat of IAS to the environment and economy, biosecurity efforts often lack suitable, scientifically-based methods to make effective management decisions, such as identifying an established IAS population from a single incursion event. We present a proof-of-concept for a new application of a stable isotope technique to identify wild and captive histories of an invasive pet species. Twelve red-eared slider turtles (Trachemys scripta elegans) from historic Australian incursions with putative wild, captive and unknown origins were analysed to: (1) present best-practice methods for stable isotope sampling of T. s. elegans incursions; (2) effectively discriminate between wild and captive groups using stable isotope ratios; and (3) present a framework to expand the methodology for use on other IAS species. A sampling method was developed to obtain carbon $\left(\delta^{13} \mathrm{C}\right)$ and nitrogen $\left(\delta^{15} \mathrm{~N}\right)$ stable isotope ratios from the keratin layer of the carapace (shells), which are predominantly influenced by dietary material and trophic level respectively. Both $\delta^{13} \mathrm{C}$ and $\delta^{15} \mathrm{~N}$ exhibited the potential to distinguish between the wild and captive origins of the samples. Power simulations demonstrated that isotope ratios were consistent across the carapace and a minimum of eight individuals were required to effectively discriminate wild and captive groups, reducing overall sampling costs. Statistical classification effectively separated captive and wild groups by $\delta^{15} \mathrm{~N}$ (captive: $\delta^{15} \mathrm{~N} \% 0 \geq 9.7 \%$, minimum of $96 \%$ accuracy). This study outlines a practical and accessible method for detecting IAS incursions, to potentially provide biosecurity staff and decision-makers with the tools to quickly identify and manage future IAS incursions.
\end{abstract}

Copyright Katherine G.W. Hill et al. This is an open access article distributed under the terms of the Creative Commons Attribution License (CC BY 4.0), which permits unrestricted use, distribution, and reproduction in any medium, provided the original author and source are credited. 


\section{Keywords}

biosecurity, invasive species, pet trade, provenancing, stable isotopes, Trachemys scripta elegans, wildlife trade

\section{Introduction}

Wildlife trade, in particular the legal and illegal pet trade, facilitates the worldwide movements of invasive alien species (IAS), providing novel introduction pathways into new environments (Russello et al. 2008, Lockwood et al. 2019). Accidental escapes or intentional release of alien pets provide numerous opportunities for these species to establish, particularly where the propagule pressure is high from repeated or mass releases (Vall-Ilosera and Cassey 2017). If new populations are not detected rapidly, complete eradication is unlikely and often extremely costly and resource-intensive (Mack et al. 2000). IAS are a key threatening process to global biodiversity loss, thus the prevention of further establishment is critical (Lodge et al. 2006, Baillie et al. 2010). Current methods for discriminating between a recently escaped or released captive individual and an individual from an established population are ineffective and rarely identify the threat early enough for effective eradication (Schmidt et al. 2017). Here, we explore the potential for a novel application of carbon and nitrogen biogeochemistry for determining the provenance of a vertebrate IAS incursion.

The relative abundance of stable isotopes within a material is a function of its synthesis and environmental history, which, in the case of vertebrate animals, predominantly relates to their diet (Camin et al. 2016). In vertebrate animal tissue, stable carbon isotope ratios (a measure of the relative abundance of ${ }^{13} \mathrm{C} /{ }^{12} \mathrm{C}$, reported as $\delta^{13} \mathrm{C}$ ) are linked to the $\delta^{13} \mathrm{C}$ of the animal's diet, which, in turn, is strongly influenced by the relative proportion of the $\mathrm{C} 3$ and $\mathrm{C} 4$ plants an animal directly or indirectly consumes. Nitrogen stable isotope ratios (a measure of the relative abundance of ${ }^{15} \mathrm{~N} /{ }^{14} \mathrm{~N}$, reported as $\delta^{15} \mathrm{~N}$ ) are also influenced by the animal's diet; specifically, they indicate the trophic position of the animal. Given that a difference in the diet between wild and captive animals is extremely likely, stable isotope ratios can potentially utilise these differences to provide information on the origin of the animal (Ziegler et al. 2018).

Stable isotopes are a well-established forensic technique and are a strong candidate for identifying the origin of IAS incursions (Cerling et al. 2016). Environmental research using stable isotopes include tracing vertebrate movements, including tracking migratory animals where satellite trackers cannot be used (e.g. MacKenzie et al. 2011, Madigan et al. 2017) and identifying diets and niche positions (e.g. Haubrock et al. 2020, Pearson et al. 2013). Previous studies have explored stable isotope tools to distinguish between wild and captive animals with success, including, but not limited to: short-beaked echidnas (Tachyglossus aculeatus) (Brandis et al. 2018); wolves (Canis lupis) (Kays and Feranec 2011); African grey parrots (Psittacus erithacus) (Alexander et al. 2019, Symes et al. 2017); reticulated pythons (Python reticulatus) (Natusch et al. 2017); and crocodile lizards (Shinisaurus crocodilurus) (van Schingen et al. 2016, Ziegler et al. 2018). In all of these cases, stable isotopes have proved efficient at iden- 
tifying environmental histories and diets. Yet, with the exception of insects (Holder et al. 2014, Hood-Nowotny et al. 2016), the use of stable isotopes for determining the provenance of IAS, early in the incursion process, is relatively unexplored.

Trachemys scripta elegans (red-eared slider turtles) were selected as a case study to test the efficacy of $\delta^{13} \mathrm{C}$ and $\delta^{15} \mathrm{~N}$ for biosecurity applications. As one of the world's top 100 most invasive species, T. s. elegans have the potential to establish and spread in urban and semi-rural areas worldwide (IUCN 2000, Rodder et al. 2009, Banha et al. 2017). T. s. elegans are the most-traded turtle species in the world, where more than 50 million individuals were exported from USA between 1989 to 1997 to supply the global pet trade (Telecky 2001) and the trade continues illegally despite being restricted in most regions (Kitowski and Pachol 2009; García-Díaz et al. 2015). These animals grow large quickly, resulting in being intentionally released into waterways when they become undesirable as pets. As a consequence, T. s. elegans have established nearly 200 identified breeding populations worldwide (Kikillus et al. 2010). They are a significant threat to biodiversity, as they compete with native turtles for food and shelter (Pearson et al. 2013, Balzani et al. 2016) and carry exotic diseases including Ranavirus and Chlamydia spp. (Johnson et al. 2007, Mitura et al. 2017). As T. s. elegans are omnivorous, the proportions of meat and plant material that may vary between wild and captive diets are likely to drive differences in $\delta^{13} \mathrm{C}$ and $\delta^{15} \mathrm{~N}$, making them good candidates for our case study.

New methodologies are urgently needed to provide early identification of incursions as distinct from established populations, to allow for quick and effective eradication (Lodge et al. 2006). Here, we present a new application of $\delta^{13} \mathrm{C}$ and $\delta^{15} \mathrm{~N}$ using historical Australian incursion samples of $T$. s. elegans of putative wild and captive origins to: (i) determine best-practice methods for sampling T. s. elegans incursions; (ii) evaluate the use of $\delta^{13} \mathrm{C}$ and $\delta^{15} \mathrm{~N}$ to discriminate between wild and captive individuals; and (iii) provide a framework to expand the methodology for use on other IAS species.

\section{Methods}

\section{Sample collection}

T. s. elegans post-mortem specimens were loaned from the Queensland Museum, the Department of Primary Industries and Regions, South Australia and the Australian Museum Research Institute Herpetology Collection. These animals were collected by state wildlife compliance agencies under their powers to seize animals being kept in contradiction to legislation or found at-large in wild environments. All animals were euthanised as per state and territory biosecurity protocols and stored frozen. The national collection contains seized T. s. elegans incursions from various locations across Australia. Due to the nature of the limited sample collection and the value of biosecurity material, twelve animals from various Australian locations (Fig. 1) with sufficient details to determine the accuracy of their environmental histories were selected, which were: (i) seized from illegal captive holding or commercial sale $(n=4)$; (ii) surrendered 


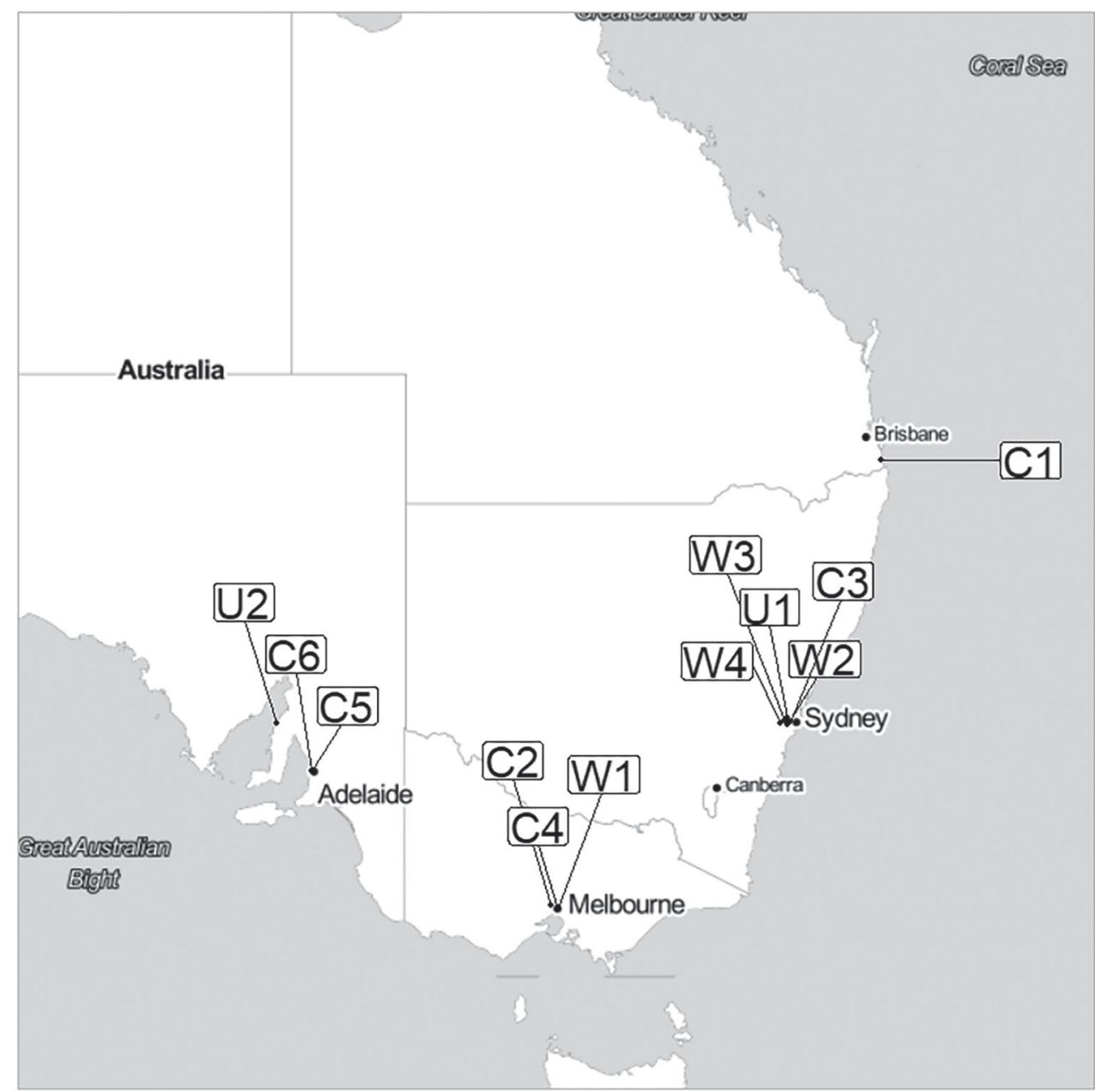

Figure I. Locations of Australian T. s. elegans incursion samples used in this study. Identified established populations exist in Sydney, New South Wales (Burgin 2006, Mo 2018) and multiple locations in Queensland (O’Keeffe 2005).

by members of the public $(n=3)$; or (iii) found at-large in wild-states $(n=5)$. Sex and age were determined by dissection and secondary characteristics, according to Gradela et al. (2017). Due to the lack of confirmed established populations, widespread sampling of different environments and, thus, potential environmental variation in $\delta^{13} \mathrm{C}$ and $\delta^{15} \mathrm{~N}$, was not possible. However, it was assumed these variances would be captured in the between-individual variation.

Based on the assumed environmental history of the individual turtles, we assigned the variable "status" and classified individuals as "wild" or "captive". While the majority of animals used in this study had relatively high confidence of their origin, there remains uncertainty in the status of individuals being correctly assigned by authorities. Therefore, we created an index to determine the percent confidence 
of correct classification, based on how many secondary characteristics matched the original assessment by authorities, including: (i) proximity to a known established population; (ii) presence of algae or wild features on the carapace; (iii) seized by authorities or surrendered by a member of the public. This provided a confidence scale for selecting the individuals used for a decision model (Suppl. material 1). Four individuals seized from captivity had $100 \%$ certainty in status, while the remaining individuals contained varying degrees of uncertainty. Individuals with less than $50 \%$ certainty were classified as "unknown" $(n=2)$.

\section{Isotopic analysis}

Measuring stable isotope ratios from a slow-turnover and inert tissue provides a longterm record of an animal's environmental history (Dalerum and Angerbjörn 2005). The keratin covering a turtles' carapace in scale-like sections (scutes) was selected due to its slow, annual growth and ease of sampling (Schneider et al. 2015). Scutes grow by adding new layers to the base, whilst widening in each layer from the perimeter to account for growth. Old scutes are then shed from the perimeter of the shell (Clinical Anatomy and Physiology of Exotic Species 2005). Assuming T. s. elegans scute growth is similar to Chrysemys picta from the same sub-family (Emydidae), a new layer of scute grows in warmer months of spring to summer, while the previous year's growth is shed; providing temporal comparisons between years (Alibardi 2005). Shed scute was available for three turtles (C1, U1 and U2), with primary scutes retained on the carapace and secondary scute peeled off after freeze-drying. On one individual, a tertiary layer was available as a second layer of peeling scute.

Carapaces were washed, removed from the body and freeze-dried to separate partially shed scutes, to exclude water contamination and to ensure only one layer of scute was sampled at a time. Samples on shed scutes were cut using sterile dissecting scissors, while shavings were collected on attached scutes using sterile scalpels. Scute samples were weighed and placed in tin capsules for continuous-flow isotope ratio mass spectrometry (CF-IRMS) using an Elementar elemental analyser coupled to a $\mathrm{Nu}$ Horizon mass spectrometer at the University of Adelaide. Standards of glycine, glutamic acid and USGS41 (L-glutamic acid; Reston Stable Isotope Laboratory 2011) were run periodically to correct for mass effects and instrumental drift during and between runs. Isotope ratios are reported in per mil (\%o), where $\delta^{13} \mathrm{C}$ is reported relative to the $\mathrm{Vi}$ enna Pee Dee Belemnite (VPDB) standard and $\delta^{15} \mathrm{~N}$ is reported relative to AIR. The values of $\delta^{13} \mathrm{C}$ and $\delta^{15} \mathrm{~N}$ were measured during the same analysis.

\section{Sampling size and design}

To improve the detectable $\delta^{13} \mathrm{C}$ and $\delta^{15} \mathrm{~N}$ separation between captive and wild groups or to increase effect size differences, the variance of each hierarchal level of sampling (indi- 
vidual > scute > sample) needed to be minimised without oversampling (Nicholson and Holmes 2017). A pilot analysis was performed to provide estimates of the variances of each hierarchal level of sampling. Calculated variances, along with proposed measures of detectable differences in isotope ratios, were used to compare different sampling designs that were generated through simulation (Green and MacLeod 2016) with the aim to determine a suitable sample size of individual animals and number of scutes and samples within scutes per individual. The most practical sampling method was determined as that with power $>80 \%$ with minimum sampling (Suppl. material 2) to detect the minimum observed difference of $\delta^{15} \mathrm{~N}$ between animals from different status groups.

\section{Analysis of turtle provenance}

Differences in mean isotope ratios amongst individual turtle specimens were evaluated using linear mixed effects models. The values of $\delta^{13} \mathrm{C}$ and $\delta^{15} \mathrm{~N}$ were fitted independently as response variables, with individual turtles as a fixed effect and scute as a random effect to allow for variation between repeated measurements within a scute. The models explicitly allowed for differences in variation between individuals, because heterogeneity within individuals violated the constant variance assumption of the linear mixed effect models. The effects of sex on $\delta^{13} \mathrm{C}$ and $\delta^{15} \mathrm{~N}$ were investigated using linear mixed effect models with and without sex as a term and examined significance of dropping different independent variables using a Pearson's chi-squared test. We were unable to investigate other variables of interest, such as location and climate, due to the broad variety of the small number of representative samples. Instead, these contribute to the between-individual variation.

The overall objective was to evaluate if a decision rule could be developed that allowed wild and captive individuals to be identified, based on their $\delta^{13} \mathrm{C}$ and $\delta^{15} \mathrm{~N}$ values. To assess this, a classification tree approach was adopted by introducing the status as a response variable. As the data consisted of multiple observations from the same individual turtles, a structured cross-validation approach was used to evaluate the prediction error, with all observations from the same individual included in the "holdout' set for prediction; and to avoid over-fitting. Individuals with an unknown status were omitted, as well as juvenile turtle W1 due to potential differences in diet between juvenile and adult turtles (Reed and Krysko 2014). The optimal classification tree was selected using the classification parameter; where misclassification errors were not significantly improved with the penalty of adding further nodes. A classification tree was constructed using this process, including all individual observations across all turtles to allow for variation within individuals. To analyse the temporal variability across the shed and retained scutes, separate linear models for each isotope were fitted, to assess changes in $\delta^{13} \mathrm{C}$ and $\delta^{15} \mathrm{~N}$ and thus, diet, over different active seasons.

All analyses were conducted in the $\mathrm{R}$ software environment for statistical and graphical computing (V 3.5.3; R Core Team 2019). Linear mixed effects models were 
fitted with the R package "lme4" (Bates et al. 2014), simulations were performed in "simr" (Green and MacLeod 2016) and classification trees with "rpart" (Trevor et al. 2009, Therneau et al. 2018).

\section{Results}

\section{Sampling size and design}

Power simulations indicated nine samples across two separate scutes on the carapace were sufficient to capture individual variation, while retaining a detectable difference between wild and captive individuals. Variation between scutes of the same layer (primary and secondary) was minimal when compared to variation between individuals. Sampling four individuals per status group ("captive" and "wild" groups, eight individual turtles in total) provided the greatest power at a minimum of $96 \%$. The position of the samples within the scute had no significant effect on $\delta^{15} \mathrm{~N}\left(\chi_{6}^{2}=1.76, p>0.05\right)$ nor $\delta^{13} \mathrm{C}\left(\chi_{6}^{2}=0.840, p>0.05\right)$.

\section{Analysis of turtle provenance}

Status (wild versus captive) was the main factor underlying differences in isotope values. There was evidence for an effect of status on isotopic ratios $\left(\chi_{1}^{2}=4.02, p=0.0451\right)$, but no clear differences between the sexes $\left(\chi_{2}^{2}=3.66, p=0.160\right)$.

Individual turtles had their own unique $\delta^{13} \mathrm{C}$ and $\delta^{15} \mathrm{~N}$ values and within-individual variation was generally less than between-individual variation (Table 1 ). Wild turtles exhibited lower $\delta^{15} \mathrm{~N}$ values and a greater spread in $\delta^{13} \mathrm{C}$ values compared to captive turtles (Fig. 2).

Table I. $\delta^{15} \mathrm{~N}$ and $\delta^{13} \mathrm{C}$ means, standard error (SE) and sample sizes $(n)$ for individual turtles.

\begin{tabular}{|c|c|c|c|c|c|}
\hline Turtle & $\delta^{15} \mathrm{~N}$ mean & $\delta^{15} \mathrm{~N} S \mathrm{E}$ & $\delta^{13} \mathrm{C}$ mean & $\delta^{13} \mathrm{C} \mathrm{SE}$ & $n$ \\
\hline$\overline{\mathrm{C} 1}$ & 13.08 & 0.40 & -21.41 & 0.22 & 25 \\
\hline $\mathrm{C} 2$ & 10.51 & 0.40 & -22.24 & 0.27 & 26 \\
\hline C3 & 10.13 & 0.42 & -21.62 & 0.66 & 18 \\
\hline C4 & 10.90 & 0.40 & -19.67 & 0.28 & 16 \\
\hline C5 & 12.58 & 0.45 & -18.33 & 0.26 & 15 \\
\hline C6 & 13.62 & 0.43 & -19.09 & 0.27 & 18 \\
\hline U1 & 8.03 & 0.40 & -22.53 & 0.27 & 18 \\
\hline U2 & 12.39 & 0.40 & -18.70 & 0.27 & 18 \\
\hline W1 & 7.42 & 0.42 & -20.09 & 0.52 & 23 \\
\hline W2 & 6.44 & 0.40 & -27.26 & 0.28 & 24 \\
\hline W3 & 8.71 & 0.42 & -25.34 & 0.32 & 26 \\
\hline W4 & 9.22 & 0.41 & -22.63 & 0.29 & 16 \\
\hline
\end{tabular}


A

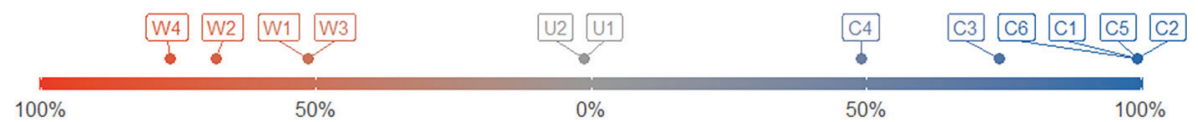

$\mathrm{B}$

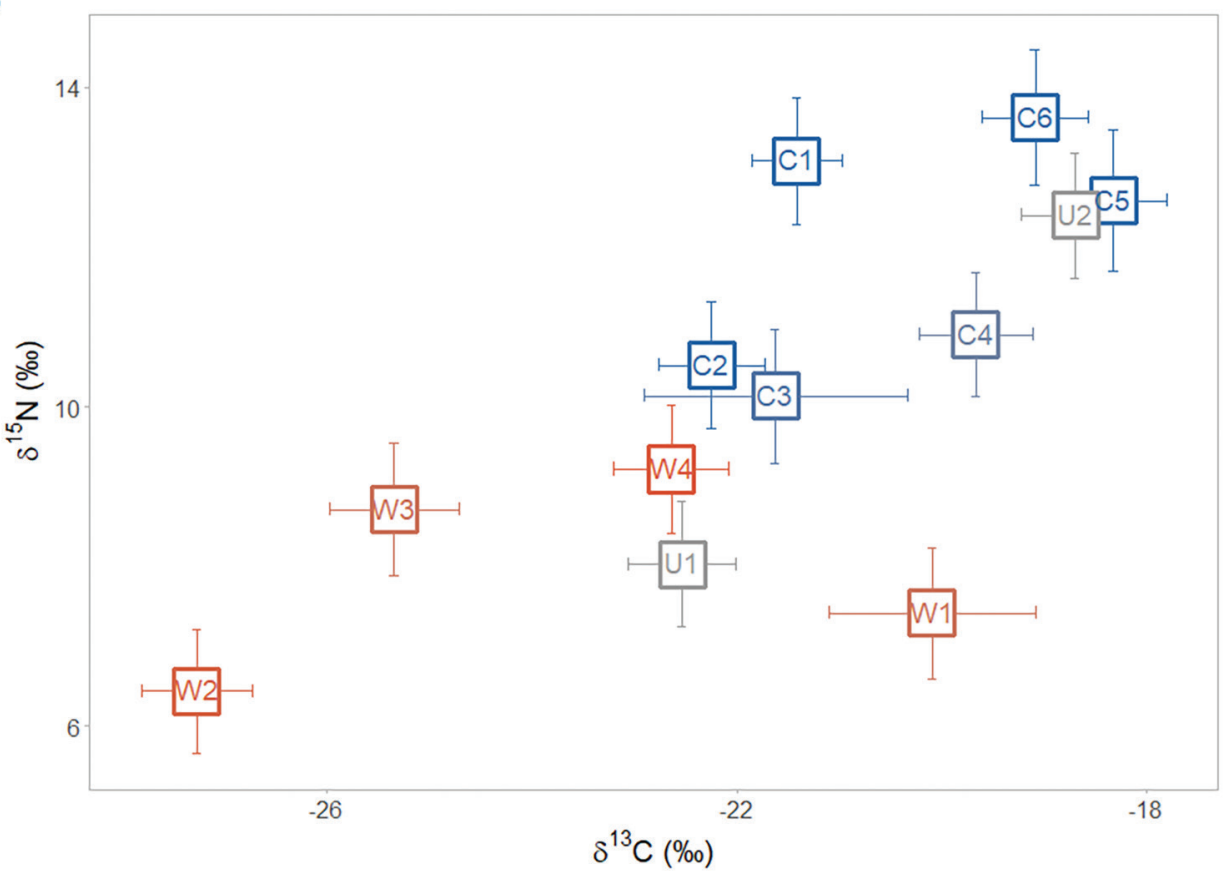

Figure 2. A Confidence in original status assignment based on select characteristics (Suppl. material 1); B plot of $\delta^{13} \mathrm{C}$ and $\delta^{15} \mathrm{~N}$ means and $95 \%$ confidence intervals for captive and wild T. s. elegans individuals, coloured according to their assignment confidence described in Figure 2A.

The classification tree showed clear differences between captive and wild groups associated with $\delta^{15} \mathrm{~N}$ (Fig. 3). Only $\delta^{15} \mathrm{~N}$ was required to separate captive and wild groups, with captive animals identified by $\delta^{15} \mathrm{~N} \% 0 \geq 9.7 \%$, with a success rate of at least $96 \%$. If $\delta^{15} \mathrm{~N}$ information was not included, groups were poorly separated with captive turtles identified by $\delta^{13} \mathrm{C} \% 0 \geq-22 \%$ with success of $81 \%$. Using the generated classification tree, the two unknown turtles "U1" and "U2" were classified as wild and captive, respectively (Fig. 3).

Of the three turtles with shed scutes available, all revealed significant differences between layers in $\delta^{13} \mathrm{C}\left(\mathrm{C} 1: F_{1,31}=100.4, p<0.0001\right.$; U1: $F_{3,51}=0.0006, p<0.0001$; $\left.\mathrm{U} 2: F_{2,34}<0.0001, p<0.0001\right)$ and $\delta^{15} \mathrm{~N}$ for turtles $\mathrm{C} 1$ and $\mathrm{U} 1\left(F_{1,31}=100.4, p<\right.$ $\left.0.0001 ; F_{2,50}=82.7, p<0.0001\right)$, but not U2 $\left(F_{1,34}=1.771, p=0.192\right)$. However, there was no consistency in the direction of change between layers. Furthermore, the $\delta^{15} \mathrm{~N}$ values for each scute layer remained within the classification range of their assigned status; "wild" and "captive". 


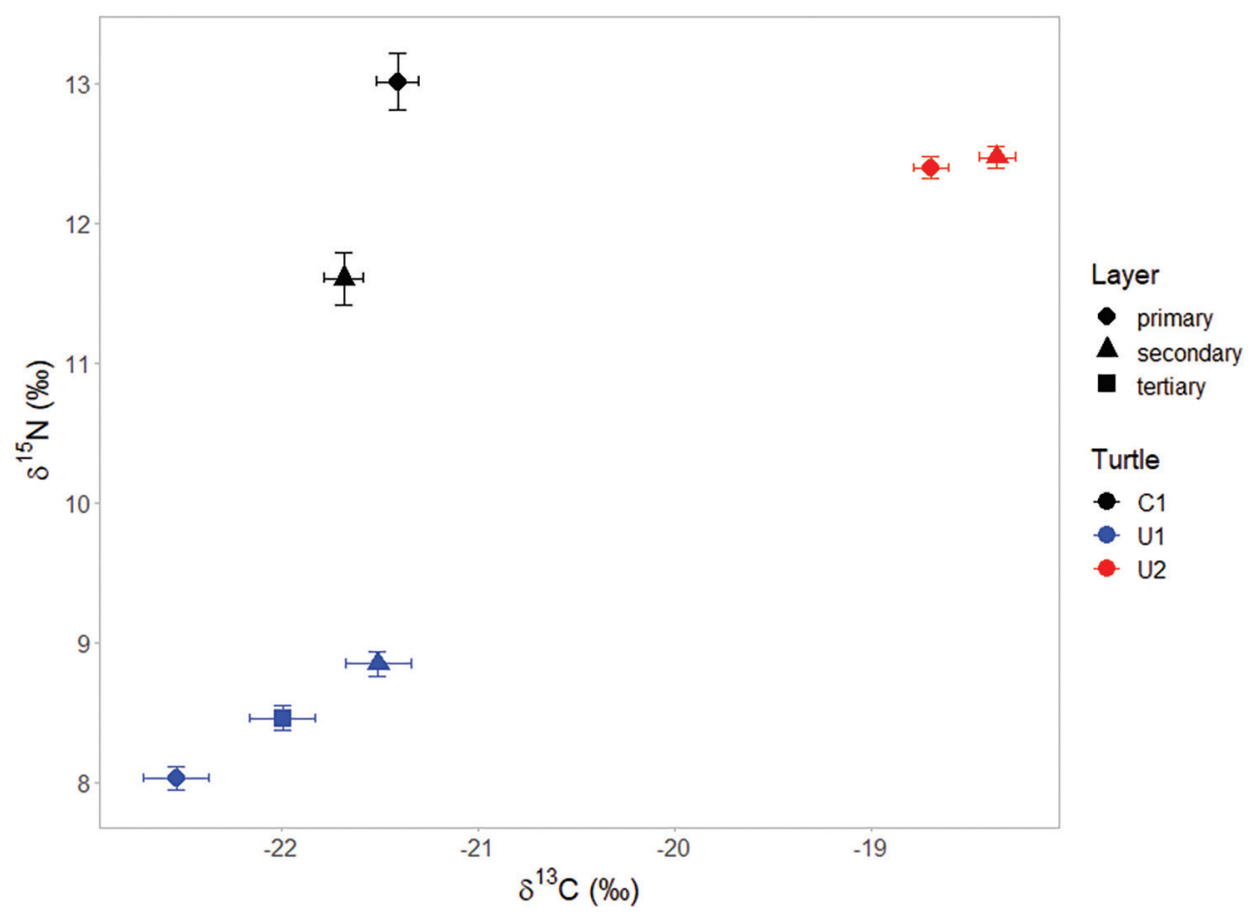

Figure 3. $\delta 13 \mathrm{C}$ and $\delta 15 \mathrm{~N}$ means and $95 \%$ confidence intervals for the shed and retained scute on three individuals: captive $\mathrm{C} 1$ and unknowns U1 and U2. Layers are labelled as primary (newest growth; retained on carapace) and secondary (older growth; shed scute). An older scute layer was available on turtle U1, named tertiary (oldest growth; retained scute).

\section{Discussion}

Captive and wild T. s. elegans are effectively differentiated by their $\delta^{15} \mathrm{~N}$. Sampling scute proved to be a simple method; no specialist equipment was required for collection and samples could be taken anywhere on the scute and across multiple scutes with minimal variation within the individual. Although individuals were dissected for this study, the use of scute shavings is potentially a non-invasive method. This makes the technology accessible for non-specialist practitioners, such as biosecurity or veterinary staff and for samples to be collected and sent to a laboratory for analysis and determination of their origins. Furthermore, the power simulations demonstrated that minimal sampling per individual is required, reducing the overall sampling costs in time, effort and welfare, as well as monetary cost.

As material of high biosecurity risk is inherently difficult to obtain, the availability of T. s. elegans and other reptile IAS is limited, while information surrounding an animal's history is not always accessible. Wild T. s. elegans specimens are rare in Australia, as at-large populations have only been confirmed in Sydney (Burgin 2006, Robey et al. 2011; Mo 2019) and Queensland (O'Keeffe 2005). Furthermore, T. s. elegans are 
illegal to import or keep in Australia without a licence, limiting available samples to those confiscated from illegal keeping (Department of Agriculture and Water Resources 2017). Here, we used a selection of samples for which we were initially confident in the assignment of status to an individual. Furthermore, the use of a power analysis demonstrated that a minimum of eight $(n \geq 8)$ individuals of known origin was sufficient to obtain a detectable effect size to effectively separate wild and captive groups.

Separation of wild and captive groups used a simple classification tree model, which effectively differentiated wild and captive individuals with minimal misclassification error. As samples with relatively high status confidence were used, this classification tree can be adopted as a set of best-practice methods and model to determine the origins of T. s. elegans individuals found in wild-states. However, further refinement of the model is required, such as including a wider range of locations of samples to improve the discrimination power.

Differences in the $\delta^{13} \mathrm{C}$ and $\delta^{15} \mathrm{~N}$ composition of scutes from different status groups are likely primarily influenced by different proportions and sources of plant and animal material within a turtle's diet, as well as varied sources of these food groups (Balzani et al. 2016). The trophic level of captive turtles, as inferred from $\delta^{15} \mathrm{~N}$, is consistently higher than for wild populations, despite potential $\delta^{15} \mathrm{~N}$ enrichment from agricultural fertilisers in wild environments (Hofmeister et al. 2013). This is likely influenced by a higher consumption of meat-based products by captive turtles, including commercial turtle food (Mazumder et al. 2018). Commercial turtle food often contains marine origin proteins, which may increase $\delta^{13} \mathrm{C}$ and $\delta^{15} \mathrm{~N}$ (Schoeninger and DeNiro 1984). A similar result has been identified in studies on other reptiles, such as crocodile lizards (Shinisaurus crocodilurus) and monitor lizards (Varanus spp.), where captive animals possessed enriched $\delta^{15} \mathrm{~N}$ (van Schingen et al. 2016, Natusch et al. 2017, Ziegler et al. 2018). Therefore, $\delta^{15} \mathrm{~N}$ is a strong candidate for the expansion of this forensic technique into other reptile groups, but likely requires species-specific validation.

The $\delta^{13} \mathrm{C}$ exhibited little power for separating wild and captive groups. As with $\delta^{15} \mathrm{~N}, \delta^{13} \mathrm{C}$ is influenced by a variety of environmental factors. However, $\delta^{13} \mathrm{C}$ was identified as the most significant separator for wild and captive juvenile T.s.scripta by Aresco and James (2005). Juvenile turtle W1 showed enrichment in $\delta^{13} \mathrm{C}$, which may be due to an ontogenetic shift in diet by adult T. s. elegans (Reed and Krysko 2014). While $\delta^{13} \mathrm{C}$ had some separating power and may be applied for a more detailed analysis of $T$. s. elegans dietary behaviour in wild and captive states, we did not find it informative as a biosecurity tool for separating adult incursions.

For each turtle, where shed scute was available, the $\delta^{15} \mathrm{~N}$ and $\delta^{13} \mathrm{C}$ exhibited significant differences between successive active seasons. However, as there was no consistent direction of change in the isotope data, it is unlikely the changes are due to tissue degradation and instead likely reflected temporal variability in the turtle's diet. The variance in $\delta^{15} \mathrm{~N}$ was sufficiently small to ensure that the specimen remained within the same status group, based on the $\delta^{15} \mathrm{~N} \% 0 \geq 9.7 \%$ o discrimination value.

It is important to note that the status assignment refers to the confidence that the turtle was wild or captive for the entirety of the scute growth period. The natal origin (birthplace) of the turtle cannot be determined using scute growth alone as scutes are 
shed yearly (Alibardi 2005). Natal origin determination requires sampling of a tissue which has remained inert since hatching, such as bone, as explored by Holder et al. (2014). Determining a tissue which has remained inert since hatching in T. s. elegans and a comparison to scute material will be extremely useful for future biosecurity efforts.

The exploration of additional biogeochemical tracers may be useful to create a more diverse set of methods and potentially obtain greater evidence of environmental origin. Stable isotopes relating to the animal's water source such as hydrogen $\left({ }^{2} \mathrm{H} /{ }^{1} \mathrm{H}\right)$ and oxygen $\left({ }^{17} \mathrm{O} /{ }^{16} \mathrm{O}\right.$ or $\left.{ }^{18} \mathrm{O} /{ }^{16} \mathrm{O}\right)$ may provide useful information on the animal's geographical origin and have been used in other animal tracking applications (Bowen et al. 2005, Hobson and Wassenaar 2018). Furthermore, controlled experiments to determine the scute-diet fractionation factor in T. s. elegans may provide greater information on the animals' diets.

\section{Conclusions}

The values of $\delta^{13} \mathrm{C}$ and $\delta^{15} \mathrm{~N}$ in scute keratin are effective at filling the requirement for the urgent need for effective forensic techniques to quickly identify the origin of T. s. elegans (red-eared slider turtle) incursions and has promising potential for applications on other high-risk IAS species (Lodge et al. 2006, McFadden et al. 2017). Stable isotope ratios in the scutes of $T$. s. elegans provide long-term information on individual environmental histories and, thus, provide an effective forensic method for identifying the origins of individuals found in wild-states. This study provides a set of best-practice, relatively accessible methods for sampling IAS incursions and subsequent analysis, including a classification tree, to determine the risk of future incursions. These approaches, using an emerging and effective forensic technique, contribute to the continuing development of various forensic techniques that are crucial for effective biosecurity efforts.

\section{Acknowledgements}

Turtle carcasses were kindly provided through scientific loans by the Queensland Museum (Patrick Couper), Department of Primary Industries and Regions, South Australia (Lindell Andrews) and Australian Museum's Herpetology Collection (Jodi Rowley and Stephen Mahoney). For sample collection and seizure information, we thank the Primary Industries and Regions SA (Lindell Andrews), the Department of Primary Industry, NSW (Alyssa Trotter, Nathan Cutter), the Elizabeth Macarthur Agricultural Institute (Brendon O'Rourke, Naomi Porter) and Department of Jobs, Precincts and Regions/Agriculture Victoria (Jesse Miller). We are extremely grateful to Mark Rollog for assistance with CFIRMS data collection, Jennifer Pistevos for her work on pilot analyses and Talia Wittmann for research assistance. This research was supported by the University of Adelaide Environment Institute, by ARC FT110100793 to F.A. McInerney and by Invasive Animals CRC (Project 1L4) and Centre for Invasive Species Solutions (Project PO1-I-002) funding to P. Cassey. An ARC LIEF grant (LE120100054) funded the IRMS used for analyses. 


\section{References}

Alexander J, Downs CT, Butler M, Woodborne S, Symes CT (2019) Stable isotope analyses as a forensic tool to monitor illegally traded African grey parrots. Animal Conservation 22: 134-143. https://doi.org/10.1111/acv.12445

Alibardi L (2005) Proliferation in the epidermis of chelonians and growth of the horny scutes. Journal of Morphology 265: 52-69. https://doi.org/10.1002/jmor.10337

Aresco MJ, James FC (2005) Ecological relationships of turtles in northern Florida lakes: a study of omnivory and the structure of a lake food web. Florida State University Tallahassee, Florida, USA.

Baillie J, Griffiths J, Turvey S, Loh J, Collen B (2010) Evolution lost: status and trends of the world's vertebrates. Zoological Society of London, London, UK.

Balzani P, Vizzini S, Santini G, Masoni A, Ciofi C, Ricevuto E, Chelazzi G (2016) Stable isotope analysis of trophic niche in two co-occurring native and invasive terrapins, Emys orbicularis and Trachemys scripta elegans. Biological Invasions 18: 3611-3621. https://doi. org/10.1007/s10530-016-1251-x

Banha F, Gama M, Anastacio PM (2017) The effect of reproductive occurrences and human descriptors on invasive pet distribution modelling: Trachemys scripta elegans in the Iberian Peninsula. Ecological Modelling 360: 45-52. https://doi.org/10.1016/j.ecolmodel.2017.06.026

Bates D, Mächler M, Bolker B, Walker S (2014) Fitting linear mixed-effects models using lme4. Journal of Statistical Software 67: 1-48. https://doi.org/10.18637/jss.v067.i01

Bowen GJ, Wassenaar LI, Hobson KA (2005) Global application of stable hydrogen and oxygen isotopes to wildlife forensics. Oecologia 143: 337-348. https://doi.org/10.1007/ s00442-004-1813-y

Brandis KJ, Meagher PJB, Tong LJ, Shaw M, Mazumder D, Gadd P, Ramp D (2018) Novel detection of provenance in the illegal wildlife trade using elemental data. Scientific Reports 8: 8. https://doi.org/10.1038/s41598-018-33786-0

Burgin S (2006) Confirmation of an established population of exotic turtles in urban Sydney. Australian Zoologist 33: 379-384. https://doi.org/10.7882/AZ.2006.011

Burleigh R, Brothwell D (1978) Studies on Amerindian dogs, 1: Carbon isotopes in relation to maize in the diet of domestic dogs from early Peru and Ecuador. Journal of Archaeological Science 5: 355-362. https://doi.org/10.1016/0305-4403(78)90054-7

Camin F, Bontempo L, Perini M, Piasentier E (2016) Stable isotope ratio analysis for assessing the authenticity of food of animal origin. Comprehensive Reviews in Food Science and Food Safety 15: 868-877. https://doi.org/10.1111/1541-4337.12219

Cerling TE, Barnette JE, Bowen GJ, Chesson LA, Ehleringer JR, Remien CH, Shea P, Tipple BJ, West JB (2016) Forensic stable isotope biogeochemistry. Annual Review of Earth and Planetary Sciences 44: 175-206. https://doi.org/10.1146/annurev-earth-060115-012303

Clinical Anatomy and Physiology of Exotic Species (2005) Chapter 3 - Tortoises and turtles. In: O’Malley B (Ed.) Clinical Anatomy and Physiology of Exotic Species. W.B. Saunders Ltd., Edinburgh, 41-56. https://doi.org/10.1016/B978-070202782-6.50006-5 
Dalerum F, Angerbjörn A (2005) Resolving temporal variation in vertebrate diets using naturally occurring stable isotopes. Oecologia 144: 647-658. https://doi.org/10.1007/s00442005-0118-0

Department of Agriculture and Water Resources (2017) Biosecurity Regulation 2016. In: DoAaW (Ed.) Resources. Canberra, Australia.

García-Díaz P, Ross JV, Ayres C, Cassey P (2015) Understanding the biological invasion risk posed by the global wildlife trade: propagule pressure drives the introduction and establishment of Nearctic turtles. Global Change Biology 21: 1078-1091. https://doi.org/10.1111/ gcb. 12790

Gradela A, Santiago TOC, Pires IC, Silva, AdCS, de Souza LC, de Faria MD, Neto JP, Milanelo L (2017) Sexual dimorphism in red-eared sliders (Trachemys scripta elegans) from the Wild Animal Triage Center of the Tiete Ecological Park, São Paulo, Brazil. Acta Scientiae Veterinariae 45: 1-10. https://doi.org/10.22456/1679-9216.80442

Green P, MacLeod CJ (2016) SIMR: an R package for power analysis of generalized linear mixed models by simulation. Methods in Ecology and Evolution 7: 493-498. https://doi. org/10.1111/2041-210X.12504

Haubrock JF, et al. (2020) When alien catfish meet - resource overlap between the North American Ictalurus punctatus and immature European Silurus glanis in the Arno River (Italy). Ecology of Freshwater Fish, 29: 4-17. https://doi.org/10.1111/eff.12481

Hobson KA, Wassenaar LI (2018) Tracking animal migration with stable isotopes. Academic Press. https://doi.org/10.1016/B978-0-12-814723-8.00001-5

Hofmeister NR, Welk M, Freedberg S (2013) Elevated levels of $\delta 15 \mathrm{~N}$ in riverine Painted Turtles (Chrysemys picta): trophic enrichment or anthropogenic input? Canadian Journal of Zoology 91: 899-905. https://doi.org/10.1139/cjz-2013-0121

Holder PW, Armstrong K, Van Hale R, Millet MA, Frew R, Clough TJ, Baker JA (2014) Isotopes and trace elements as natal origin markers of Helicoverpa armigera - an experimental model for biosecurity pests. PLOS ONE 9: e92384. https://doi.org/10.1371/journal. pone.0092384

Hood-Nowotny R, Mayr L, Saad N, Seth RK, Davidowitz G, Simmons G (2016) Towards incorporating insect isotope analysis using cavity ring-down spectroscopy into areawide insect pest management programs. Florida Entomologist 99: 177-184. https://doi. org/10.1653/024.099.sp121

Hu Y, Luan F, Wang S, Wang C, Richards MP (2009) Preliminary attempt to distinguish the domesticated pigs from wild boars by the methods of carbon and nitrogen stable isotope analysis. Science in China Series D: Earth Sciences 52: 85-92. https://doi.org/10.1007/ s11430-008-0151-z

IUCN (2000) IUCN guidelines for the prevention of biodiversity loss caused by alien invasive species. In: International Union for the Conservation of Nature. Gland, Switzerland.

Johnson AJ, Pessier AP, Jacobson ER (2007) Experimental transmission and induction of ranaviral disease in western ornate box turtles (Terrapene ornata ornata) and red-eared sliders (Trachemys scripta elegans). Veterinary Pathology 44: 285-297. https://doi.org/10.1354/ vp.44-3-285 
Kays R, Feranec R (2011) Using stable carbon isotopes to distinguish wild from captive wolves. Northeastern Naturalist 18: 253-264. https://doi.org/10.1656/045.018.0301

Kikillus KH, Hare KM, Hartley S (2010) Minimizing false-negatives when predicting the potential distribution of an invasive species: a bioclimatic envelope for the red-eared slider at global and regional scales. Animal Conservation 13: 5-15. https://doi.org/10.1111/ j.1469-1795.2008.00299.x

Kitowski I, Pachol D (2009) Monitoring the trade turnover of red-eared terrapins (Trachemys scripta elegans) in pet shops of the Lublin region, east Poland. North-Western Journal of Zoology 5: 34-39.

Lockwood JL, Welbourne DJ, Romagosa CM, Cassey P, Mandrak NE, Strecker A, Leung B, Stringham OC, Udell B, Episcopio-Sturgeon DJ, Tlusty MF, Sinclair J, Springborn MR, Pienaar EF, Rhyne AL, Keller R (2019) When pets become pests: the role of the exotic pet trade in producing invasive vertebrate animals. Frontiers in Ecology and the Environment 17: 323-330. https://doi.org/10.1002/fee.2059

Lodge DM, Williams S, MacIsaac HJ, Hayes KR, Leung B, Reichard S, Mack RN, Moyle PB, Smith M, Andow DA (2006) Biological invasions: recommendations for US policy and management. Ecological Applications 16: 2035-2054. https://doi.org/10.1890/10510761(2006)016[2035:BIRFUP]2.0.CO;2

Mack RN, Simberloff D, Lonsdale WM, Evans H, Clout M, Bazzaz FA (2000) Biotic invasions: causes, epidemiology, global consequences, and control. Ecological Applications 10: 689-710. https://doi.org/10.1890/1051-0761(2000)010[0689:BICEGC]2.0.CO;2

MacKenzie KM, Palmer MR, Moore A, Ibbotson AT, Beaumont WRC, Poulter DJS, Trueman CN (2011) Locations of marine animals revealed by carbon isotopes. Scientific Reports 1: 21. https://doi.org/10.1038/srep00021

Madigan D, Baumann Z, Carlisle A, Snodgrass O, Dewar H, Fisher N (2017) Isotopic insights into migration patterns of Pacific bluefin tuna in the eastern Pacific Ocean. Canadian Journal of Fisheries and Aquatic Sciences 75: 260-270. https://doi.org/10.1139/ cjfas-2016-0504

Mazumder D, Johansen MP, Fry B, Davis E (2018) Muscle and carapace tissue-diet isotope discrimination factors for the freshwater crayfish Cherax destructor. Marine and Freshwater Research 69: 56-65. https://doi.org/10.1071/MF16360

McFadden MS, Topham P, Harlow PS (2017) A ticking time bomb: is the illegal pet trade a pathway for the establishment of corn snake (Elaphe guttata) populations in Australia? Australian Zoologist 38: 499-504. https://doi.org/10.7882/AZ.2017.006

Mitura A, Niemczuk K, Zareba K, Zajac M, Laroucau K, Szymanska-Czerwinska M (2017) Free-living and captive turtles and tortoises as carriers of new Chlamydia spp. PLOS ONE 12: 15 . https://doi.org/10.1371/journal.pone.0185407

Mo M (2019) Red-eared Sliders Trachemys scripta elegans in southern Sydney, including new incursions. Australian Zoologist 40: 314-325. https://doi.org/10.7882/AZ.2018.022

Natusch DJD, Carter JF, Aust PW, Tri NV, Tinggi U, Mumpuni, Riyanto A, Lyons JA (2017) Serpent's source: determining the source and geographic origin of traded python skins using isotopic and elemental markers. Biological Conservation 209: 406-414. https://doi. org/10.1016/j.biocon.2017.02.042 
Nicholson G, Holmes C (2017) A note on statistical repeatability and study design for highthroughput assays. Statistics in Medicine 36: 790-798. https://doi.org/10.1002/sim.7175

O'Keeffe S (2005) Investigating in conjecture: eradicating the red-eared slider in Queensland. In: 13th Australasian Vertebrate Pest Conference. Te papa, Wellington, New Zealand, 169-176 pp.

Pearson SH, Avery HW, Kilham SS, Velinsky DJ, Spotila JR (2013) Stable isotopes of C and $\mathrm{N}$ reveal habitat dependent dietary overlap between native and introduced turtles Pseudemys rubriventris and Trachemys scripta. PLOS ONE 8: e62891. https://doi.org/10.1371/ journal.pone.0062891

R Core Team (2019) R: a language and environment for statistical computing. R Foundation for Statistical Computing, Vienna, Austria.

Reed RN, Krysko, KL (2014) Chapter 28 - Invasive and introduced reptiles and amphibians. In: Mader DR, Divers SJ (Eds) Current Therapy in Reptile Medicine and Surger. W.B. Saunders, St. Louis, 304-309. https://doi.org/10.1016/B978-1-4557-0893-2.00028-4

Reston Stable Isotope Laboratory (2011) Report of stable isotopic composition. Reference material USGS41. United States Geological Survey, Reston, Virginia.

Robey J, Burgin S, Hitchen DJ, Ross G (2011) Status of an urban feral red-eared slider (Trachemys scripta elegans) population in Sydney a decade on. Australian Zoologist 35: 822-825. https://doi.org/10.7882/AZ.2011.033

Rodder D, Schmidtlein S, Veith M, Lotters S (2009) Alien invasive slider turtle in unpredicted habitat: a matter of niche shift or of predictors studied? PLOS ONE 4: e7843. https://doi. org/10.1371/journal.pone.0007843

Russello MA, Avery ML, Wright TF (2008) Genetic evidence links invasive monk parakeet populations in the United States to the international pet trade. Bmc Evolutionary Biology 8: 11. https://doi.org/10.1186/1471-2148-8-217

Schmidt B, Stevenson K, Bloink C (2017) Surveys for the smooth newt (Lissotriton vulgaris) in south-east Melbourne. Ecology Australia Pty Ltd, Melbourne.

Schneider L, Eggins S, Maher W, Vogt RC, Krikowa F, Kinsley L, Eggins SM, Da Silveira R (2015) An evaluation of the use of reptile dermal scutes as a non-invasive method to monitor mercury concentrations in the environment. Chemosphere 119: 163-170. https://doi. org/10.1016/j.chemosphere.2014.05.065

Schoeninger MJ, DeNiro MJ (1984) Nitrogen and carbon isotopic composition of bone collagen from marine and terrestrial animals. Geochimica et Cosmochimica Acta 48: 625-639. https://doi.org/10.1016/0016-7037(84)90091-7

Symes C, Skhosana F, Butler M, Gardner B, Woodborne S (2017) Isotope (delta C-13, delta $\mathrm{N}-15$, delta $\mathrm{H}-2$ ) diet-tissue discrimination in African grey parrot Psittacus erithacus: implications for forensic studies. Isotopes in Environmental and Health Studies 53: 580-596. https://doi.org/10.1080/10256016.2017.1319832

Telecky TM (2001) United States import and export of live turtles and tortoises, 8-13.

Therneau T, Atkinson B, Ripley B, Ripley MB (2018) rpart: Recursive Partitioning and Regression Trees.

Trevor H, Robert T, JH F (2009) The elements of statistical learning: data mining, inference, and prediction. New York, NY: Springer. 
Vall-Ilosera M, Cassey P (2017) Leaky doors: private captivity as a prominent source of bird introductions in Australia. PLOS ONE 12: e0172851. https://doi.org/10.1371/journal. pone. 0172851

van Schingen M, Ziegler T, Boner M, Streit B, Nguyen TQ, Crook V, Ziegler S (2016) Can isotope markers differentiate between wild and captive reptile populations? A case study based on crocodile lizards (Shinisaurus crocodilurus) from Vietnam. Global Ecology and Conservation 6: 232-241. https://doi.org/10.1016/j.gecco.2016.03.004

Ziegler S, Giesen K, van Schingen M, Rauhaus A, Ziegler T (2018) Testing the applicability of $15 \mathrm{~N}$ isotopic marker in skin tissue to distinguish between captive and wild monitor lizards, 73-83.

\section{Supplementary material I}

Tables S1.1, S1.2. A detailed description of indexes used for calculating confidence of status of Trachemys scripta elegans individuals

Authors: Katherine G. W. Hill, Kristine E. Nielson, Jonathan J. Tyler, Francesca A. McInerney, Zoe A. Doubleday, Greta J. Frankham, Rebecca N. Johnson, Bronwyn M. Gillanders, Steven Delean, Phill Cassey

Data type: species data

Copyright notice: This dataset is made available under the Open Database License (http://opendatacommons.org/licenses/odbl/1.0/). The Open Database License $(\mathrm{ODbL})$ is a license agreement intended to allow users to freely share, modify, and use this Dataset while maintaining this same freedom for others, provided that the original source and author(s) are credited.

Link: https://doi.org/10.3897/neobiota.59.53671.suppl1

\section{Supplementary material 2}

Table S2.1; Figure S1. Explanation of methods for determining the optimal sampling size and design, using a power analysis on pilot data

Authors: Katherine G. W. Hill, Kristine E. Nielson, Jonathan J. Tyler, Francesca A. McInerney, Zoe A. Doubleday, Greta J. Frankham, Rebecca N. Johnson, Bronwyn M. Gillanders, Steven Delean, Phill Cassey

Data type: statistical data

Copyright notice: This dataset is made available under the Open Database License (http://opendatacommons.org/licenses/odbl/1.0/). The Open Database License $(\mathrm{ODbL})$ is a license agreement intended to allow users to freely share, modify, and use this Dataset while maintaining this same freedom for others, provided that the original source and author(s) are credited.

Link: https://doi.org/10.3897/neobiota.59.53671.suppl2 


\section{Supplementary material 3}

\section{Figure S1. Results from a carbon decision tree}

Authors: Katherine G. W. Hill, Kristine E. Nielson, Jonathan J. Tyler, Francesca A. McInerney, Zoe A. Doubleday, Greta J. Frankham, Rebecca N. Johnson, Bronwyn M. Gillanders, Steven Delean, Phill Cassey

Data type: statistical data

Copyright notice: This dataset is made available under the Open Database License (http://opendatacommons.org/licenses/odbl/1.0/). The Open Database License $(\mathrm{ODbL})$ is a license agreement intended to allow users to freely share, modify, and use this Dataset while maintaining this same freedom for others, provided that the original source and author(s) are credited.

Link: https://doi.org/10.3897/neobiota.59.53671.suppl3

\section{Supplementary material 4}

\section{Table S4.1. Determining confidence in status assignment}

Authors: Katherine G. W. Hill, Kristine E. Nielson, Jonathan J. Tyler, Francesca A. McInerney, Zoe A. Doubleday, Greta J. Frankham, Rebecca N. Johnson, Bronwyn M. Gillanders, Steven Delean, Phill Cassey

Data type: statistical data

Copyright notice: This dataset is made available under the Open Database License (http://opendatacommons.org/licenses/odbl/1.0/). The Open Database License (ODbL) is a license agreement intended to allow users to freely share, modify, and use this Dataset while maintaining this same freedom for others, provided that the original source and author(s) are credited.

Link: https://doi.org/10.3897/neobiota.59.53671.suppl4 